17. sendo qualquer das multas imposta por órgão ou empresa pública ou autarquia federal, a competência será deslocada para a Justiça Federal, a teor do que está contido no art. 109, I, da Constituição Federal

18. a via judicial cabível para combater-se esse ti po de ilegalidade pode ser o mandado de segurança ou uma ação ordinária, mas aquele só será possível se houver direito líquido e certo demonstrável de pronto com a inicial, enquanto que a ação ordinária deverá ser a via eleita no caso de haver necessidade de produção de provas, além da documental.

19. no mandado de segurança, que depende de prova pré-constituída, o reconhecimento da nulidade das multas é possível

20. no caso de falta de notificação regular, inclusive quanto ao prazo legal, a autoridade não poderá regularizar posteriormente a situação e cobrar a multa, pois ocorre decadência.

21. a notificação, para ser válida, tem que ser efetiva, não bastando sua mera expedição, embora não se exija mão-própria

22. caso o interessado pretenda receber uma liminar em mandado de segurança ele de verá desde logo apresentar uma certidão negativa de notificação expedida pela autoridade que aplicou a multa combatida

23. em casos excepcionais o juízo pode oficia determinando o envio da certidão necessária, mas não será cabível a liminar de pronto, só após a chegada da certidão

24. se o interessado não quiser ou não puder esperar pela resposta, poderá entrar com ação ordinária pedindo tutela anteci pada e prestando caução

25. a prestação de caução também é possível, excepcionalmente, em alguns casos de mandado de segurança, de acordo com o poder geral de cautela do juiz

26. cabe à autoridade impetrada provar a legalidade e veracidade do ato de imposição da multa quando houver alegação de falta de notificação, não valendo aí a presunção relativa a esse respeito

\title{
Argumentação Jurídica e a Imunidade do Livro Eletrônico
}

\author{
Tumberto Ávila
}

Advogado em Porto Alegre. Prof. da PUC/RS (Grad./Mest.) e da Escola Superior da Magistratura do RGS (AJURIS)

Especialista em Finanças e Mestre em Direito (UFRGS)

Certificado de Estudos em Metodologia e Doutorando em Direito (Universidade de Munique, Alemanha).

"Ob der Satz wahr oder falsch ist, wird durch die Erfahrung entschieden, aber nicht sein Sinn". (A experiência decide se o enunciado é verdadeiro ou falso, mas não o seu sentido).

LUDWIG WTTTGENSTEIN

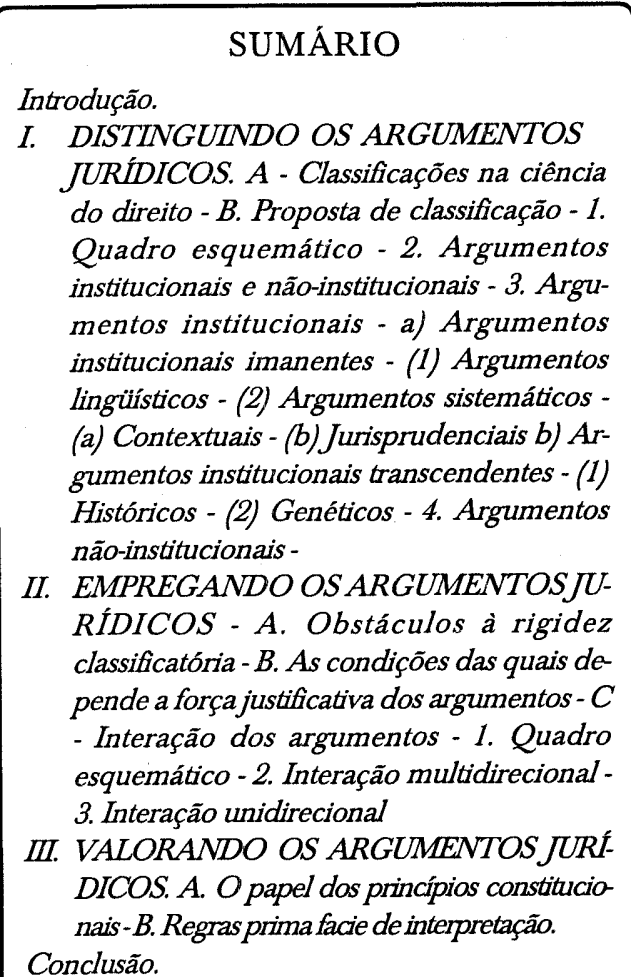

Conclusão.

\section{INTRODUÇÃO}

ara decidir pela imunidade dos "livros eletrônicos", parte da doutrina percorre, das premissas até a conclusão, um processo dedutivo análogo a este: (a) os livros são protegidos pela imunidade; (b) todas as obras que veiculam idéias e são dispostas em seqüência lógica são livros; (c) o chamado "livro eletrônico" consiste numa obra que veicula idéias e é disposta em seqüência lógica; (d) o "livro eletrônico" é um livro; (e) o "livro eletrônico" é protegido pela imunidade dos livros, jornais e periódicos.

Para decidir pelo não-enquadramento dos "livros eletrônicos" no âmbito material da regra de imunidade, outra parte da doutrina percorre, das premissas até a conclusão, um processo dedutivo semelhante ao que segue: (a) os livros são protegidos pela imunidade; (b) todas as obras encadernadas e ordenadas em folhas de papel são livros; (c) o chamado "livro eletrônico" não consiste numa obra encadernada $e$ ordenada em folhas de papel; (d) o "livro ele- 
trônico" não é um livro; (e) o "livro eletrônico" não é protegido pela imunidade dos livros, jornais e periódicos.

Como se vê, esse processo dedutivo, que contém o núcleo da fundamentação racional, é o que se convém chamar de justificação interna, mediante a qual se pode avaliar se o juizo decorre logicamente das premissas. A justificação interna não consiste numa fundamentação completa, na medida em que as premissas resolutivas nas duas hi póteses apresentadas (premissas "b"), que decidem efetivamente sobre uma interpretação - restritiva ou extensiva do vocábulo livro e pela inclusão do conceito de "livro eletrônico" no conceito de "livro", são meramente aplicadas na justificação interna. Não são, porém, fundamentadas. Ê dizer: tanto a premissa "todas as obras que veiculam idéias e são dispostas em seqüência lógica são livros", quanto a premissa "todas as obras encadernadas e ordenadas em folhas de papel são livros" são aplicadas sem ser justificadas. É que sua justificação depende de argumentos: os argumentos são elementos de justificação racional da interpretação jurídica. ${ }^{1} \mathrm{E}$ a tarefa da interpretação jurídica é, precisamente, fundamentar esse tipo de premissa. Esse trabalho de fundamentação da premissa escolhida convém seja qualificado de justificação externa, mediante a qual são avaliados os argumentos empregados para decidir por uma interpretação em detrimento de outra(s). ${ }^{2}$

A discussão a respeito do enquadramento do "livro eletrônico" na classe de objetos abrangidos pela imunidade dos livros e periódicos

tem sido matéria de notáveis estudos doutrinários. ${ }^{3}$ Neles, torna-se evidente a inevitáve discordância dos autores no tocante à conclusão sobre o tema tratado: enquanto alguns concluem pela inclusão do "livro eletrônico" no conceito normativo de "livros", outros decidem pelo seu não-enquadramento. Essa disparidade de interpretação não se restringe à compreensão do "livro eletrônico" no gênero "livros"; a discordância vai além, para alcançar os próprios argumentos que são utilizados pelos autore para justificar as premissas que adotam. E são, afinal, esses argumentos que decidem pela in clusão, ou não, do "livro eletrônico" no âmbito material da regra de imunidade dos livros, jor nais e periódicos.

Com efeito, os argumentos empregado para justificar a inclusão do "livro eletrônico" na classe dos "livros" são tão variados quanto os seguintes: o "livro eletrônico" seria usado, atualmente, como uma espécie de "livro"; a inserção do "livro eletrônico" na classe dos "livros" evitaria a contradição com princípios constitucionais fundamentais; o "livro eletrônico" consistiria num simples meio, equivalente ao livro, para garantir a liberdade de expressão e de informação; de acordo com o Supremo Tribunal Federal, imunidade em apreço deveria ser interpretada de acordo com a finalidade que visa a alcançar; o "livro eletrônico" significaria, hoje, aquilo que o "livro" representou ontem.

Os argumentos aplicados para fundamentar o não-enquadramento do "livro eletrônico" da classe dos "livros" são igualmente diversificados: a expressão "e o papel destinado a sua

MacCORMICK, Neil. SUMMERS, Robert. Interpretation and Justification. In: Interpreting statutes: a comparative study. Org: Idem. Aldershot, Brokfeld, Hong Kong, Singapore, Sydney: Dartmouth, 1992. p. 511.

2 ALEXY, Robert. Juristische Interpretation. In: Recht, Vernunft, Diskurs: Studien zur Rechtsphilosophie. 1 Aufl. Frankfurt am Main: Suhrkamp, 1995. p. 71-92

3 MACHADO, Hugo de Brito. Coord. Imunidade tributária do livro eletrônico. São Paulo: Informações Objetivas. 1998. MARTINS, Ives Gandra da Silva. Imunidades Tributárias. São Paulo: Editora Revista dos Tribunais: Centro de Extensão Universitária, 1998 (Pesquisas tributárias, Nova série; n. 4).

Revista da Faculdade de Direito da UFRGS, v. 19, Março/2001 impressão" afastaria da imunidade qualquer objeto que não fosse feito de papel; o vocábulo "CD-ROM" teria acepção técnica diversa da de "livro"; o Supremo Tribunal Federal já teria decidido só haver livro onde há papel; ao mencionar o papel no dispositivo constitucional, o legislador constituinte teria objetivado proteger apenas o livro impresso em papel; a proposta de inclusão do "livro eletrônico" teria sido rejeitada pelo legislador constituinte; não tributar o "livro eletrônico" traria perda significativa de receita para o Estado no futuro.

Que todos esses argumentos podem ser utilizados na interpretação da imunidade em comento, não há dúvida; hesitação existe, contudo, quanto a saber se todos eles têm a mesma importância jurídica. Como será analisado, os argumentos usados na interpretação não são juridicamente equivalentes. Eles têm fundamentos desiguais e, por isso, valores diferentes. Não podem, por conseqüência, nem ser empregados indistintamente, nem ser tomados um pelo outro, como se fora a sua escolha e a sua valoração uma manifestação de mero capricho do intérprete.

O objetivo deste estudo não se circunscreve aos argumentos que podem ser utilizados na interpretação jurídica (da imunidade dos "livros eletrônicos"), matéria essa já objeto de excelentes publicações; ele abrange, também, o debate sobre a especificidade de cada argumento e sobre a sua própria dimensão de peso no direito brasileiro. Não se pretende apenas criar condições para que se saiba por que são escolhidas determinadas alternativas de interpretação (razões explicativas ou subjetivas); intenta-se, também, apresentar critérios para valorar as decisões de interpretação de acordo com o

ordenamento jurídico (razões justificativas ou objetivas). ${ }^{4}$

Para tanto, é preciso, em primeiro lugar, diferenciar os argumentos em função de seu fundamento; em segundo lugar, valorar cada um deles com base no ordenamento jurídico brasileiro. Lá, um discurso sobre o discurso da ciência do direito (discurso metateórico), na medida em que apresenta uma alternativa de qualificação dos argumentos empregados no discurso doutrinário; aqui, um discurso sobre o ordenamento jurídico (discurso teórico), enquanto explica coerentemente quais são as implicações metodológicas dos princípios constitucionais relativamente aos argumentos empregados najustificação de premissas do raciocínio jurídico.

Não se pretende apenas descrever como os argumentos estão sendo de fato aplicados pela doutrina e pela jurisprudência na interpretação jurídica. $O$ fato de eles estarem sendo empregados dessa ou daquela forma não quer dizer que não poderiam ou deveriam ser utilizados de outra maneira. Este trabalho pretende explicar, outrossim, como os argumentos podem e devem ser utilizados na interpretação jurídica. ${ }^{5}$ Para alcançar esse propósito utilizou-se um verdadeiro caso-limite, que proporciona a análise dos vários argumentos empregados na interpretação jurídica.

I - DISTINGUINDO OS ARGUMENTOS JURÍDICOS

A. Classificaçốes na ciência do direito

As classificações elaboradas pela ciência do direito, enquanto voltadas à explicação coe-

NINO, Carlos Santiago. La validez del derecho. Buenos Aires: Astrea, 1985. p. 126

BYDLINSKI, Franz.Juristische Methodenlehre und Rechtsbegriff. 2. ed. Wien-New York: Springer, 1991.p 554. ALEXY, Robert Juristische Interpretation. In: Recht, Vernunft, Diskurs: Studien zur Rechtsphilosophie. 1. ed. Frankfurt am Main: Suhrkamp, 1995. p. 78.

Revista da Faculdade de Direito da UFRGS, v. 19, Março/2001 
rente do ordenamento jurídico, submetem-se a limites dele decorrentes. Com efeito, será a compatibilidade com o ordenamento jurídico que permitirá avaliar a procedência da classificação, por exemplo, da eficácia das normas constitucionais, dos efeitos das decisões judiciais ou das espécies tributárias; o exame do ordenamento jurídico poderá confirmar ou infirmar a existência de normas de eficácia limitada, a subsistência de decisões sem nenhum efeito declaratório ou mesmo a possibilidade de exclusão da finalidade e da destinação da arrecadação como critérios para a divisão dos tributos em espécies. A nomenclatura e a variedade de divisões e subdivisões dos objetos classificados irá, porém, variar de acordo com a finalidade e o critério a que serve $o$ agrupamento. Nesse quadro, as classificações serão mais ou menos adequadas à explicação de determinado objeto. ${ }^{6}$

É verdade que fazer as distinções entre os argumentos pode conduzir à rigidez classificatória; e a rigidez classificatória pode levar à desconsideração da multi plicidade de relações entre os argumentos diferenciados, bem como pode deixar de fazer frente ao caráter prático-institucional do Direito. Não é menos verdade, no entanto, que deixar de fazer as devidas distinções entre os argumentos pode levar à arbitrariedade argumentativa; e a arbitrariedade argumentativa conduz à não-fundamentação das premissas utilizadas na interpretação jurídica. Com efeito, tanto a ausência de definição dos argumentos utilizados quanto a falta de di- ferenciação entre eles inserem, na interpretação jurídica, o germe da ambigüidade e, com ele, a fonte da arbitrariedade. Isso porque a mera

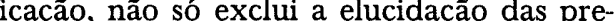
missas, como permite conclusões díspares e até

Como será demonstrado, não basta mencionar qual o argumento que está sendo emutilizadas na interpretação. Dizer que a linguagem, o sistema, o legislador constituinte ou resultados práticos decidem determinada interpretação é simplesmente pretender sejam unidirecionais argumentos que fluem em várias direções.

Classificações dos argumentos empregados na interpretação jurídica existem várias, $\mathrm{e}$ de consistência. Há mais discordância com relação à nomenclatura da distribuição em classes do que disparidade com relação à construção dos grupos. Divergências fundamentais existem quanto à relação entre os argumentos e quanto às regras atinentes à prevalência de um sobre outro. A proposta aqui defendida vai além das obras que lhe serviram de alicerce. ${ }^{7}$. Propõe-se uma reclassificação dos argumentos jurídicos integrada com uma utilização e valoração móvel e flexível desses mesmos argumentos. síntese superadora que harmonize a necessidamenção a argumentos, sem a sua necessária jusmesmo inconciliáveis entre si. pregado para justificar a escolha das premissas

O objetivo deste estudo é construir uma

6 Sobre classificações em geral, ver: CARVALHO, Paulo de Barros. IPI - Comentários sobre as Regras Gerais de Interpretação da Tabela NBMSSH (TIPI/TAB). Revista Dialética de Direito Tributário (12): 53 e ss., São Paulo, 1996.

' ALEXY, Robert.Juristische Interpretation. In: Recht, Vernunft, Diskurs: Studien zur Rechtsphilosophie. 1. ed. Frankfurt am Main: Suhrkamp, 1995. p. 71-92. MÜLLER, Friedrich.Juristische Methodik. 7. ed. Berlin: Duncker und Humblot. 1997. p. 216-303. BYDLINSKI, Franz.Juristische Methodenlehre und Rechtsbegriff. 2 ed. Wien-New York: Springer, 1991 p. 553566. GUASTINI Riccardo. Distinguendo: sudi di teoria e

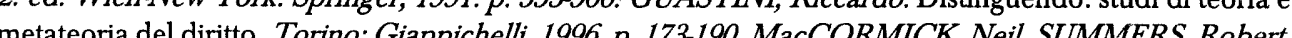
Interpretation andJustification. In: Interpreting statutes: a comparative study. Org. Idem. Aldershot, Brokfeld, Hong Kong, Singapore, Sydney: Dartmouth, 1992

Revista da Faculdade de Direito da UFRGS, v. 19, Março/2001 de de discernir os argumentos com a importância de não os separar por completo, diminuindo a inevitável subjetividade da interpretação sem enrijecer o raciocínio para o futuro. Com isso, poder-se-á abanc simplismo na argumentação jurídica, quer

no sentido de reduzir o raciocínio jurídico à pura lógica ou à pura interpretação literal, quer no sentido de circunscrever a atividade interpretativa ao mero decisionismo ou à simples ponderação de valores de natureza inexplicada. ${ }^{8}$

B. Proposta de classificação

1 - Quadro esquemático

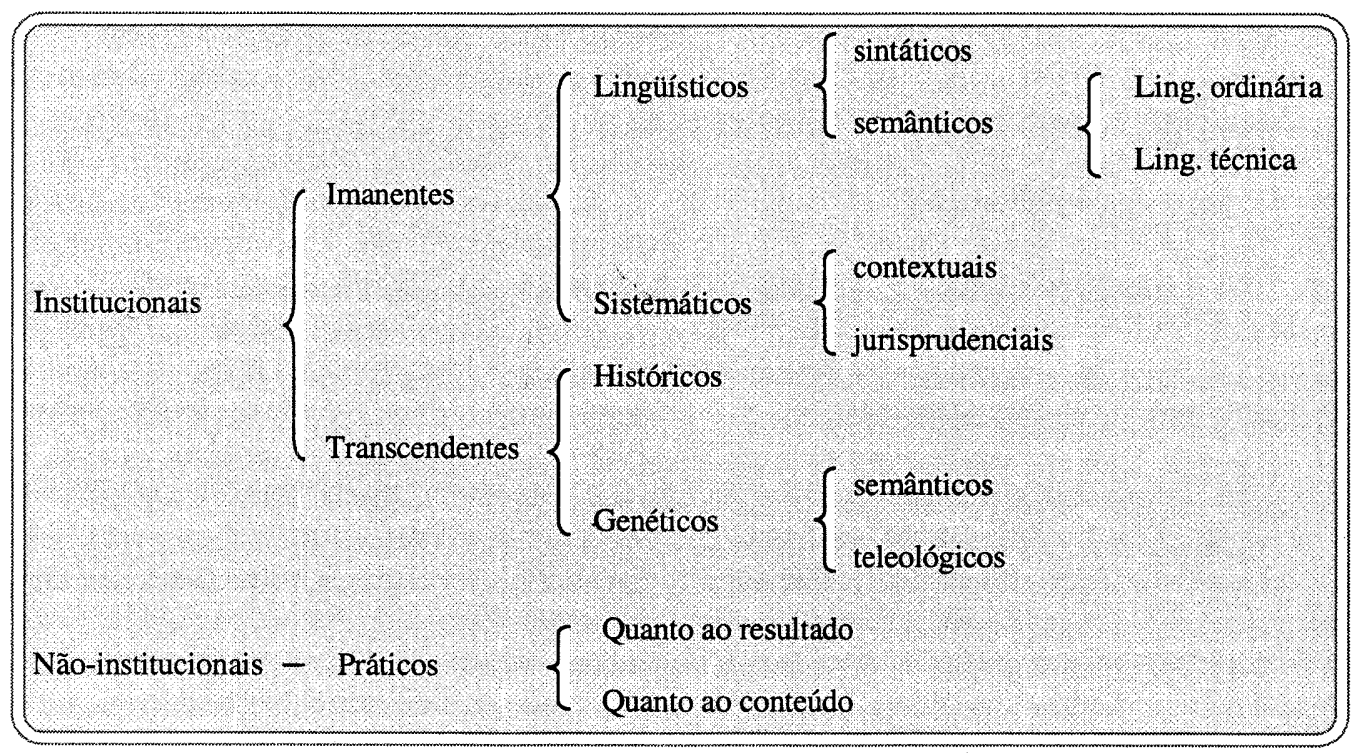

2- Argumentos institucionais e nãoinstitucionais

A primeira grande divisão dos argumentos empregados na interpretação jurídica é aqueaqueles que, sobre serem determinados por atos institucionais - parlamentares, administrativos, judiciais -, têm como ponto de referência o

ordenamento jurídico. Possuem, nesse sentido, maior capacidade de objetivação. Os argumentos não-institucionais são decorrentes apenas do apelo ao sentimento de justiça que a própria interpretação eventualmente evoca. ${ }^{9}$ Possuem, por isso, menor capacidade de objetivação

Os argumentos institucionais subdividem-

s BYDLINSKI, Franz.Juristische Methodenlehre und Rechtsbegriff. 2. ed. Wien-New York: Springer, 1991 p. 553.

${ }^{9}$ ALEXY, Robert. Juristische Interpretation. In: Recht, Vernunft, Diskurs: Studien zur Rechtsphilosophie. 1. ed. Frankfurt am Main: Suhrkamp, 1995. p. 87.

Revista da Faculdade de Direito da UFRGS, v. 19, Març/2001 
ordenamento jurídico positivo. ${ }^{10}$ Os argumentos institucionais imanentes são aqueles que são construídos a partir do ordenamento jurídico vigente, assim da sua linguagem textual e contextual como dos seus valores e da sua estrutura. Os argumentos institucionais transcendentes são aqueles que não mantêm relação com $o$ ordenamento jurídico vigente, mas dizem respeito ou a sua formação ou ao sentido dos dispositivos que ele antes continha.

\section{3- Argumentos institucionais}

A. Argumentos institucionais imanentes
(1) Argumentos lingüísticos

Os argumentos institucionais imanente ao sistema jurídico, apesar de unidos numa totalidade de sentido, podem ser teoricamente discernidos em lingüísticos e sistemáticos.

Os argumentos lingǘisticos dizem respeito ao significado dos dispositivos ou enunciados prescritivos. Eles podem ser qualificados como semânticos, quando referentes ao significado das expressões; e sintáticos, quando relacionados a sua estrutura gramatical. Os argumentos semânticos podem, ao seu turno, fazer referência tanto ao uso comum da linguagem (linguagem ordinária) quanto a sua utilização técnica (linguagem técnica). A utilização técnica da linguagem pode decorrer tanto de uma definição legislativa ou doutrinária quanto do uso por especialistas na matéria. ${ }^{11}$

Se as normas são inteligiveis no contexto da linguagem ordinária, elas devem ser inter pretadas de acordo com o significado que um cidadão médio iria atribuir-lhe como sendo significado mais imediato, ao menos que existam razões suficientes para uma interpretação diversa. $^{12}$

$\mathrm{Na}$ análise da linguagem, pode-se utilizar o argumentum e contrario, mediante o qual se entende que o dispositivo, ao regular somente um caso, silenciou quanto aos outros ou os excluiu do seu âmbito de aplicação.

Pode-se interpretar a imunidade do "livro eletrônico" com base em argumento lingüísticos. De acordo com o significado comum das expressões constantes do dispositivo constitucional (argumento semântico relativo à linguagem ordinária), pode-se, focalizando a palavra "livro eletrônico", sustentar que ela é usada como sinônimo de "livro". Nesse sentido, enquadra-se o "livro eletrônico" na imunidade dos "livros". Ocorre que o significado comum das expressões igualmente se presta para interpretar o dispositivo constitucional noutra direção. É que se pode, agora voltando a atenção para o vocábulo "papel" e com o reforço da própria estrutura sintática da frase, excluir do abrigo da imunidade qualquer objeto que não seja feito com esse material. ${ }^{13}$ É possível, no entanto, sustentar que a palavra "papel" não é decisiva, na medida em que existem obras que são feitas de papel, mas que na acepção consti-

10 BORGES, José Souto Maior. O Direito como fenômeno lingüístico, o problema de demarcação da ciência jurídica, sua base empírica e o método hi potético-dedutivo. In: Ciência Feliz. Recife: Fundação de Cultura da jurídica, sua base empírica e o métod

" GUASTINI, Riccardo. Distinguendo: studi di teoria e metateoria del diritto. Torino: Giappichelli, 1996. p. 175.

12 MacCORMICK, Neil. SUMMERS, Robert Interpretation and Justification. In: Interpreting statutes: a comparative study. Org. Idem. Aldershot, Brokfield, Hong Kong, Singapore, Sydney: Dartmouth, 1992. p. 513. eletrônicos". In: MACHADO, Hugo de Brito. Coord. Imunidade tributária do livro eletrônico. São Paulo: Informações Objetivas. 1998. p. 86.

Revista da Faculdade de Direito da UFRGS, v. 19, Março/2001
13 TORRES, Heleno Taveira. GARCLA, Vanessa Nobell. Tributação e imunidade dos chamados "livros tucional não configuram livros (e. g. livros em branco, caderno em espiral, livro ponto, livro de atas). ${ }^{14}$

É dizer: o significado comum das expressões contidas no dispositivo constitucional não resolve a questão de saber se o "livro eletrônico" se enquadra na imunidade dos "livros". O significado de livro é complexo e ambíguo. ${ }^{15}$ Isso porque a relação entre a linguagem e a realidade a qual ela se refere não é natural (causal), mas convencional: é resultado de convenções lingüísticas. ${ }^{16}$ Além disso, a significação da comunicação legislada não preexiste ao ato interpretativo: ela deve ser construída pelo in térprete. $^{17}$

O mesmo ocorre com os argumentos ligados ao significado técnico das expressões constantes do dispositivo (argumento semântico relativo à linguagem técnica). De acordo com ele, pode-se, esquadrinhando o significado técnico atribuído ao vocábulo "CD-ROM" por especianidade qualquer objeto que não seja tecnicamente chamado de "livro". ${ }^{18}$ Ocorre que o significado técnico das expressões também se presta para atribuir outro sentido ao dispositivo constitucional. É que se pode, desta feita perscrutando o significado técnico do vocábulo "livro", sustentar que sua acepção técnica inclui o próprio "livro em CD-ROM". Vale dizer: também o significado técnico das expressões contidas no

dispositivo constitucional não decide a questão de saber se o "livro eletrônico" se enquadra na imunidade dos "livros". Ele corre em várias direções.

No mesmo sentido, utilizando o argumentum e contrario, pode-se sustentar tanto que o dispositivo, porque contém a expressão "e o papel destinado a sua impressão", teria restringido a imunidade às obras feitas de papel, quanto que o dispositivo, ao utilizar a referida expressão, teria deixado de regular as obras feitas com outros materiais. Lá, é afastada a imunidade dos "livros eletrônicos"; aqui, pelo menos não excluída.

\section{(2) Argumentos sistemáticos}

Os argumentos sistemáticos, a despeito de serem fundados na estrutura do sistema juridico, dizem respeito aos seus elementos ou sua aplicação. Eles são decorrência das condições formais de interpretação do próprio sistema jurídico: relação entre parte e todo (consistência e coerência), e entre norma e fato (generalização e individualização). Por meio delas, evita-se e supera-se a contradição entre os elementos do sistema, ganhando-se, pela combinação entre os elementos e pela superação das contradições, em consistência, e pelo significado advindo do conjunto de todos os elementos, em coerência. listas em informática, excluir do abrigo da imu-

If CARRAZZA, Roque Antonio. Liviro eletrônico - Imunidade Tributária - Exegese do art. 150, VI, “d”, da Constituição Federal. In: MACHADO, Hugo de Brito. Coord. Imunidade tributária do livro eletrônico. São Constituição Federal. In: MACHADO, Hugo

15 TORRES, Ricardo Lobo. Imunidade tributária nos produtos de informática. In: MACHADO, Hugo de Brito. Coord. Imunidade tributária do livro eletrônico. São Paulo: Informaçôes Objetivas. 1998. p. 200.

16 BULYGIN, Eugenio. Sull'interpretazione giuridica. In: Analisi e Diritto 1992: recerche di giurisprudenza analitica. Org. Paolo Comanducci e Riccardo Guastini. Torino: Giappichelli, 1992.

17 CARVALHO, Paulo de Barros. Proposta de modelo interpretativo para o direito tributário. In: Revista de Direito Tributário (70):42, São Paulo: Malheiros.

18 SANTI, Eurico Marcos Diniz de. Imunidade tributária como limite objetivo e as diferenças entre "livro" $e$ "livro eletrônico". In: MACHADO, Hugo de Brito. Coord. Imunidade tributária do livro eletrônico. São Paulo: Informaçóes Objetivas. 1998. p. 54.

Revista da Faculdade de Direito da UFRGS, v. 19, Marso/2001 
Os argumentos sistemáticos subdividem- "livro eletrônico" com base em argumentos se em argumentos contextuais e jurisprudenciais.

(a) Argumentos contextuais

Os argumentos contextuais dizem respe to às outras normas que, juntamente com a norma objeto da interpretação, fazem parte do sistema jurídico e devem ser consideradas na in terpretação. Variados são os argumentos contextuais.

Em primeiro lugar, os relativos aos princípios que possam ser combinados, lógica ou teleologicamente, com a norma objeto de interpretação. ${ }^{19}$ A concretização dos princípios constitucionais - enquanto normas imediatamente finalísticas - conduz a técnicas especificas de argumentação. ${ }^{20}$ Por exemplo: em razão do princípio da igualdade, e mediante o emprego do argumento a simili ou analógico, atribui-se mesma conseqüência normativa estabelecida para determinado caso a outro caso semelhan te. ${ }^{21} \hat{E}$ também nesse âmbito que são aplicados os critérios para solucionar as antinomias. ${ }^{22}$

Também se incluem nesse grupo os argumentos relativos ao lugar onde o dispositivo se encontra no documento legislativo (argumento topográfico) e à constância terminológica. ${ }^{23}$

É possível interpretar a imunidade do contextuais. Com base nos princípios constitucionais, pode-se sustentar que os "livros eletrônicos" estão abrangidos pela imunidade, na medida em que a tributação poderá envolve atentados à livre manifestação do pensamento valor que a Constituição de 1988 buscou preservar. ${ }^{24}$ Ocorre que os argumentos contextuais se prestam para interpretar o dispositivo constitucional também noutra direção. É que se poderia interpretar as imunidades combinando-as com as regras de competência, para concluir mediante uma interpretação restritiva, que a única exceção ao poder impositivo constitucionalmente atribuído ao Estado é a tributação dos livros de papel. Isso significa que os argumentos contextuais também não decidem, a rigor, a questão de saber se o "livro eletrônico" se enquadra na imunidade dos "livros". Eles podem ser utilizados em vários sentidos, embora se possa notar uma certa convergência dos argumen tos contextuais princi piais no sentido de garantir a imunidade do "livro eletrônico".

Quando a finalidade do dispositivo fo obtida levando-se em consideração os princípios constitucionais a cuja concretização serve a regra objeto de interpretação, pode-se falar em uma interpretação teleológico-sistemática. Nessa hipótese, não se pode separar a interpretação sistemática da teleológica. ${ }^{25}$ Sua consideração pode levar à utilização da técnica da redu-

19 ALEXY, Robert Theorie der juristischen Argumentation. 2. ed. Frankfurt am Main: Suhrkamp, 1991. p. 295.

D ÁVILA, Humberto Bergmann. A distinção entre princípios e regras e a redefinição do dever de proporcionalidade. RDA, 215:151-179. 1999.

21 GUASTINL, Riccardo. Distinguendo: studi di teoria e metateoria del diritto. Torino: Giappichelli, 1996. p. 180.

22 FREITAS, Juarez. A interpretação sistemática do Direito. São Paulo: Malheiros, 1995. p. 57.

${ }^{23}$ GUASTINI, Riccardo. Distinguendo: sudi di teoria e metateoria del diritto. Torino: Giappichelli, 1996. p. 190.

24 BORGES, José Souto Maior. Imunidade tributária dos produtos de informática (ICMS/IPI/SSS), Repertório IOB de Jurisprudência, $n^{\circ} 2496$, p. 545. CARRAZZA, Roque Antonio. Livro eletrônico - Imunidade Tributária - Exegese do art. 150, VI, "d", da Constituição Federal. In: MACHADO, Hugo de Brito. Coord. Imunidade tributária do livro eletrônico. São Paulo: Informaçôes Objetivas. 1998. p. 230.

${ }_{25}$ ENGISH, Karl. Einführung in das juristische Denken. 8. ed. Stuttgart Berlin; Köh: Kohlhammer, 1983. p. 79.

Revista da Faculdade de Direito da UFRGS, v. 19, Março/200 ção teleológica (redução do sentido do dispositivo por ser ele muito amplo em relação a sua finalidade) e da extensão teleológica (ampliação do sentido do dispositivo por ser ele muito restrito em relação a sua finalidade) ${ }^{26}$

Pode-se interpretar a imunidade do "livro eletrônico" com base em argumento teleológicos. Utilizando a extensão teleológica, é possivel sustentar que a palavra "livro", se en tendida como obra encadernada, é muito restrita em relação à finalidade da imunidade, que é a de garantir a liberdade de informação dos ci dadãos; pode-se também sustentar que o sentido comum da palavra "papel" é muito restrito relativamente à garantia de liberdade de acesso à informação, razão por que deve ser interpre tada de modo a abranger qualquer material adequado à produção de uma obra cultural Seja lá como for, o exposto já basta para demonstrar que os argumentos teleológicos, de pendendo da finalidade e da técnica interpretativa, também não decidem a questão de saber se o "livro eletrônico" se enquadra n imunidade dos "livros", embora reste evidente quanto a eles, a existência de uma confluência em direção ao enquadramento dos "livros eletrônicos" na imunidade em pauta.

(b) Argumentos jurisprudenciais

Os argumentos jurisprudenciais dizem respeito aos precedentes do Poder Judiciário relativamente à norma objeto de interpretação. A pertinência dos precedentes depende da norma objeto de intepretação.

Tratando-se de norma constitucional, e sendo o Supremo Tribunal Federal o órgão constitucionalmente incumbido de interpretar

CANARIS, Claus-Wilhelm. Die Feststellung von Lücken im Gesetz. 2. ed. Berlin: Duncker und Humblot, 1983. pp. 82 e ss.

27 Recurso Extraordinário n. 1449004, Primeira Turma, Rel. Min. Ilmar Galvāo, DJ 26.09.97.

28 Recurso Extraordinário n ${ }^{\circ}$ 89.590, Primeira Turma, Relator: Ministro Rafael Mayer. DJ 10.09.79.

Revista da Faculdade de Direito da UFRGS, v. 19, Março/2001

Constituição Federal, seus acórdãos exercem papel fundamental na construção do significado de qualquer norma constitucional. Na avalicão da relevância do precedente para o sentido da norma objeto de interpretação, é imprescindível ater-se às características da decisão, se de mérito ou de não-conhecimento, se proveniente de uma das Turmas ou do Tribunal Pleno, se por unanimidade ou por maioria, se em controle difuso ou em controle concentrado de constitucionalidade. Mais relevante ainda é a

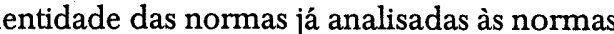
objeto de interpretação.

Pode-se interpretar a imunidade do "liro eletrônico" com base em argumentos urisprudenciais. Nesse sentido, é possivel sustentar a imunidade em comento com base na interpretação da jurisprudência do Supremo Tribunal Federal, se analisadas aquelas decisões que interpretam de maneira sistemática e extensiva as imunidades.

A Primeira Turma do Supremo TribunalFederal interpreta de modo sistemático e com base no elemento teleológico as imunidades quando, ao examinar o dispositivo constitucioque menciona a imunidade das "instituições de educação e de assistência social, sem fin ucrativos", incluiu na imunidade a eventual renda obtida pela instituição de assistência social mediante cobrança de estacionamento de eículos em área interna da entidade, destinada ao custeio das atividades desta; ${ }^{27}$ e também quando entendeu que a palavra 'patrimônio' deve ser interpretada de maneira a abranger o mposto de importação e o imposto sobre produtos industrializados, apesar deles não serem classificados pelo Código Tributário Nacional como impostos sobre o patrimônio. ${ }^{28}$

- 
A Segunda Turma do Supremo Tribunal Federal segue a mesma interpretação ampliativa, quando não afasta da imunidade renda obtida pelo SESC na prestação de serviços de diversão pública, mediante a venda de ingressos de cinema ao público em geral, que aproveitada em suas finalidades assistenciais ${ }^{29}$, ou quando inclui na imunidade até mesmo os imóveis utilizados como residência dos mem bros da entidade beneficiente..$^{30}$ No mesmo sentido, a Segunda Turma entendeu ser impertinente a característica de generalidade dos partici pantes e beneficiários para atribuir naturez pública a uma instituição, sendo importante apenas os fins sociais aos quais a entidade atende. ${ }^{31} \mathrm{Em}$ todos esses casos, a interpretação da imunidade levou em conta a finalidade de garantir a prestação de serviços de assistência social.

Especificamente com relação à imun dade dos livros e periódicos, o Supremo Tribunal Federal tem adotado uma interpretação que modifica o sentido mais imediato do dispositivo (interpretação corretiva) com utilização do argumento a simili.

Mesmo que o dispositivo constituciona tenha utilizado o vocábulo "papel", o Pleno do Supremo Tribunal incluiu no seu campo de aplicação, não só o papel utilizado diretamente na confecção dos bens referidos, mas também insumos nela consumidos como são os filmes e

papéis fotográficos. ${ }^{32}$ Segundo o mesmo Tribunal Pleno, é de se entender que "não estão excluídos" da imunidade os 'periódicos' que cuidam apenas e tão somente de informaçōes genéricas ou específicas, sem caráter noticioso, discursivo, literário, poético ou filosófico, mas de 'inegável utilidade pública', como é o caso das listas telefônicas. ${ }^{33}$ Ainda: o Pleno do Tribunal entendeu que a razão de ser da imunidade prevista no texto constitucional está no interesse da sociedade em ver afastados procedimentos capazes de inibir a produção material e intelectual de livros, jornais e periódicos, razão por que a imunidade alcançaria não só o papel utilizado diretamente na confecção dos bens referidos, como também insumos nela consum dos como são os filmes e papéis fotográficos. ${ }^{34}$

No mesmo sentido, a Primeira Turma entendeu que a imunidade é de ser entendida como abrangente de qualquer material suscetível de ser assimilado ao papel utilizado no processo de impressão. ${ }^{35}$

Em direção análoga a Segunda Turma: ainda que o dispositivo constitucional tenha feito menção ao vocábulo "periódico", a revista técnica foi incluída no seu campo de aplicação; ${ }^{36}$ mesmo que o dispositivo constitucional tenha mencionado os objetos "livros, jornais e periódicos", "estendeu-se" a proteção constitucional à fase de comercialização, ${ }^{37}$ o livro, como objeto da imunidade tributária, não é "apenas"

23 Agravo Regimental em Agravo de Instrumento no 155822-0, Primeira Turma, Relator: Ministro Ilmar Galvão, DJ 02.06.95. Recurso Extraordinário n ${ }^{\circ} 116.1884$ - SP, Primeira Turma, Relator: Ministro Sydney Sanches, DJ 16.03.1990.

\ Recurso Extraordinário nº 221.395-8, Segunda Turma, Relator: Ministro Marco Aurélio, DJ 12.05.2000

${ }^{31}$ Recurso Extraordinário nº 108.796, Segunda Turma, Relator: Ministro Carlos Madeira, DJ 12.09.86.

32 Recurso Extraordinário n. 190.761-4, Tribunal Pleno, Relator: Ministro Marco Aurélio, DJ 12.12.97.

33 Recurso Extraordinário no 101.441, Tribunal Pleno, Relator: Ministro Sydney Sanches, DJ 19.08.88.

${ }^{34}$ Recuso Extraordinário no 174.476, Tribunal Pleno, Relator para o Acórdâo: Ministro Marco Aurélio, DJ 12.12.97.

${ }^{35}$ Recurso Extraordinário n. 193.883-8, Primeira Turma, Relator: Ministro Ilmar Galvão, DJ 01.08.97.

3 Recurso Extraordinário n ${ }^{0} 77.867$, Segunda Turma, Relator: Ministro Leitão de Abreu, DJ 08.01.75.

3 Recurso Extraordinário n ${ }^{o}$ 109.484, Segunda Turma, Relator: Ministro Célio Borja, DJ: 27.05.88.

Revista da Faculdade de Direito da UFRGS, v. 19, Março/2001 o produto acabado, mas o conjunto de serviços que o realiza, desde a redação, até a revisão de obra, "sem restrição" dos valores que o formam e que a Constituição protege. ${ }^{38}$

Em todos esses casos, o Supremo Tribunal Federal, em vez de se ater isoladamente aos vocábulos constantes dos dispositivos constitucionais, buscou seu sentido em consonância com o princípio constitucional do livre acesso à informação. Embora controvertida essa qualificação, a interpretação da Alta Corte nesses casos pode ser qualificada como "corretiva" ou "ampliativa". Nesse sentido, a imunidade dos "livros" deveria abranger também os "livros eletrônicos": o "livro eletrônico", também, é meio para melhorar o acesso à informação.

Ocorre que é igualmente possível defen der o não-enquadramento do "livro eletrônico" na imunidade dos livros com base na mesma jurisprudência do Supremo Tribunal Federal, se analisadas aquelas outras decisōes que interpretam de maneira "restritiva" ou "literal" a imunidades.

Mesmo que a Constituição exclua da munidade apenas as atividades com finalidade lucrativa, entendeu a Primeira Turma não haver imunidade no caso de produção e venda de pães. ${ }^{39}$ Embora o dispositivo constitucional não faça distinções relativamente à imunidade quanto ao contribuinte de direito e de fato, a Primeira Turma circunscreveu a imunidade ao tributos que repercutem economicamente sobre o contribuinte de direito, excluindo da imuni-

Recurso Extraordinário no 102.141, Segunda Turma, Relator: Ministro Carlos Madeira, DJ 29.11.85.

30 Recurso Extraordinário no 134.573, Primeira Turma, Relator: Ministro Moreira Alves, DJ 29.09.95.

to Recurso Extraordinário n. 191.067-4, Primeira Turma, Relator: Ministro Moreira Alves, DJ 03.12.99.

${ }^{41}$ Recurso Extraordinário no 129.930, Segunda Turma, Relator: Ministro Mário Guimarães, DJ 16.08.91.

42 Recurso Extraordinário no 238.570, Segunda Turma, Relator: Ministro Néri da Silveira. Revistra Trimestral de Jurisprudência do STF $n^{\circ} 171 / 356$

43 Recurso Extraordinário no 74.032, Segunda Turma, Relator: Ministro Bilac Pinto, DJ 16.02.73.

" Recurso Extraordinário no 71.009, Segunda Turma, Relator: Ministro Antônio Neder, DJ08.03.74. de bens fabricados por entidade de assistência

A Segunda Turma do Supremo Tributambém interpreta de modo mais as imunidades quando, ao analisar quando entende que não há livro, periódico do produto final assegurado pela imunidade. ${ }^{42}$ A mesma Segunda Turma interpreta de modo previstas no conteúdo mais imede exercício de atividade alheia às finalidades essenciais da autarquia ${ }^{43}$. Apesar de a Constida Turma não haver imunidade, se houver exerde atividade atípica pelas instituições de ducação, como no caso de exploração de liRevista da Faculdade de Direito da UFRGS, v. 19, Março/200 dade aqueles que repercutem sobre o contribu- 

decisões que adotam semelhante interpretação periódicos, o Supremo Tribunal Federal tem literal e restritiva.

A Primeira Turma do Supremo Tribunal Federal interpreta de modo restritivo as imunidades, quando ao examinar o vocábulo "periódicos" contido no dispositivo, criou uma distinção nele inexistente, na medida em que excluiu da imunidade as publicações técnicas periódicas com periodicidade fixada pelo Ministério das Comunicações, como as listas telefônicas (entendimento ultrapassado pelo Pleno)..$^{45}$ Relativamente à imunidade dos livros, a Primeira Turma entende que a tinta especial para jornais não está abrangida pela imunidade. ${ }^{40}$

A Segunda Turma do Supremo Tribunal Federal interpreta de modo literal as imunidades, quando, ao analisar o vocábulo "papel", entendeu que apenas os materiais a ele relacionados (papel fotográfico; papel telefoto; filmes fotográficos, sensibilizados, não impressionados, para imagens monocromáticas; papel fotográfi co para fotocomposição por laser) é que estão abrangidos pela imunidade tributária do art. 150, VI, d, da Constituição Federal. ${ }^{47}$ Essa interpretação focaliza a linguagem ordinária do dispositivo, utilizando o argumento a contrario, não, porém, no sentido de entender que a menção apenas ao "papel" indicaria existir uma lacuna a respeito de outros materiais (argumento interpretativo com declaração de lacuna), mas no sentido de que a menção a "papel" teria positivamente excluído outros materiais (argumento produtivo com técnica de integração). ${ }^{48}$

Em todos esses outros casos, o Supremo Tribunal Federal fixou-se nos vocábulos constantes no dispositivo constitucional, sempre com a finalidade de restringir a imunidade. A interpretação da Alta Corte poderia ser qualificada como "restritiva". Nesse sentido, poder-se-ia sustentar que a jurisprudência do Supremo Tribunal estaria direcionada a não englobar os "livros eletrônicos" na imunidade dos "livros".

Como se vê, não é a rigor possível falar de uma jurisprudência unidirecional do Supremo Tribunal Federal relativamente às imunidades, em especial à imunidade dos livros. O que se pode notar é apenas uma cumulação de argumentos em favor de uma interpretação extensiva das imunidades pelas Turmas e, sobretudo, pelo Tribunal Pleno.

(b)Argumentos institucionais transcendentes

\section{(1) Argumentos históricos}

Os argumentos históricos dizem respeito à investigação do problema objeto de regulação pelas normas hoje válidas, de modo a recompor o sentido que a norma tinha ao ser editada, atualizando-a no tempo. ${ }^{49}$

Os argumentos históricos não se confundem com os argumentos genéticos: enquanto os argumentos históricos fazem referência a textos normativos anteriores, e com semelhante âmbito de incidência relativamente ao da nor-

${ }^{45}$ Recurso Extraordinário n ${ }^{\circ}$ 104.563, Primeira Turma, Relator: Ministro Oscar Correa, DJ: 05.09.86.

4 Recurso Extraordinário no 215.435 , Primeira Turma, Relator Moreira Alves.

4 Recurso Extraordinário n. 177657-9, Segunda Turma, Rel. Min. Carlos Velloso, DJ 30.05.97.

48 GUASTINI, Riccardo. Distinguendo: studi di teoria e metateoria del diritto. Torino: Giappichelli, 1996. p. 176.

4 ALEXY, Robert.Juristische Interpretation. In: Recht, Vernunft, Diskurs: Studien zur Rechtsphilosophie. 1. ed. Frankfurt am Main: Suhrkamp, 1995. p. 87.

Revista da Faculdade de Direito da UFRGS, v. 19, Março/2001 ma objeto de interpretação, os argumentos ge néticos dizem respeito a textos não-normativo (discussões parlamentares, projetos de lei, dis cursos legislativos, exposições de motivos), e se referem à formação do próprio dispositivo objeto de interpretação. ${ }^{50} \mathrm{O}$ argumento histórico faz normalmente apelo à "natureza das coisas", na medida em que procura demonstrar que, em decorrência das mutações históricas, o significado literal do dispositivo não mais se molda à realidade do momento da aplicação. ${ }^{51}$

Os argumentos históricos suscitam várias questões no que diz respeito à imunidade do "livro eletrônico". Com efeito, pode-se sustenta que o "livro eletrônico" significa, hoje, o que "livro" significou no momento da constituinte. Do ponto de vista histórico-evolutivo, pode-se até mesmo afirmar que o "livro eletrônico" nada mais significa que a interpretação de acordo com o sentido do vocábulo "livro" mencionado pel Constituição no momento da interpretação (interpretação diacrônica).

\section{(2) Argumentos genéticos}

Os argumentos genéticos dizem respeito à vontade do legislador, tanto no que se refere ao significado que o legislador teria ligado determinada expressão (argumento genético semântico-subjetivo), quanto à finalidade que ele teria pretendido atingir (argumento genético teleológico-subjetivo)

Da mesma forma, com base na vontade do legislador constituinte, pode-se tanto incluir quanto excluir o "livro eletrônico" da imunida- de dos livros: de um lado, pode-se, focalizando o pretenso significado que o legislador teria livro eletrônico" teria tido sua imunidade rejeitada; de outro, pode-se, aqui voltando a atenção para a suposta finalidade que o legislador constituinte teria pretendido atingir, defender a imunidade apenas dos livros feitos em papel. Embora sejam ambos argumentos genéticos, eles são de espécies diferentes: enquanto o primeiro avalia o pretenso significado do projeto (argumento genético semântico-subjetivo), o segundo examina a pressuposta finalidade da proposta (argumento genético teleológico-subjetivo). É dizer: simplesmente fazer menção à vontade do legislador não é bastante para justificar nenhuma conclusão.

\section{4 - Argumentos não-institucionais}

Os argumentos não-institucionais não fazem referência aos modos institucionais de existência do Direito. Eles fazem apelo a qualquer outro elemento que não o próprio ordenamento jurídico. São argumentos meramente práticos que dependem de um julgamento, feito pelo próprio intérprete, sob pontos de vista econômicos, políti$\cos$ e/ou éticos. ${ }^{52}$ As conseqüências danosas de determinada interpretação e a necessidade de atentar para os planos de governo enquadram-se aqui.

Pode-se interpretar a imunidade do "livro eletrônico" com base em argumentos meramente práticos. É possível sustentar que seria absurdo aceitar a incidência de impostos sobre gado à proposta aprovada, sustentar que o "li-

so MÜLLER, Friedrich.Juristische Methodik. 7. ed. Berlin: Duncker und Humblot. 1997. p. 245.

${ }_{51}$ GUASTINL, Riccardo.Distinguendo: studi di teoria e metateoria del diritto. Torino: Giappichelli, 1996. p. 178.

2 MacCORMICK, Neil. SUMMERS, Robert. Interpretation and Justification. In: Interpreting statutes: a comparative study. Org. Idem. Aldershot, Brokfeld, Hong Kong, Singapore, Sydney: Dartmouth, 1992. p 521. ALEXY, Robert. Juristische Interpretation. In: Recht, Vernunft, Diskurs: Studien zur Rechtsphilosophie. 1. ed. Frankfurt am Main: Suhrkamp, 1995. p. 89. 
"livros eletrônicos" e sobre quaisquer meios modernos de comunicação e de comércio Noutro giro, porém, é possível afirmar que não-incidência de impostos sobre "livros eletrônicos", exatamente por serem eles o mecanismo moderno de comunicação e de comércio, irá excluir a maior fonte de receita estatal nos dias atuais. Os argumentos não-institucionais não são conclusivos relativamente à imunidade do "livro eletrônico". Aliás, justamente pela falta de referência a pontos de vista objetivos ou objetiváveis, os argumentos não-institucionais nunca serão conclusivos, porque mani pulávei arbitrariamente conforme os interesses em jogo.

\section{EMPREGANDO OS ARGUMENTOS JURÍDICOS}

A. Obstáculos à rigidez classificatória

Diante do que foi acima exposto, resta evidente a necessidade de especificar, tanto quanto possível, cada um dos argumentos empregados na interpretação jurídica. A particularização de cada argumento encontra, porém

Em primeiro lugar, a classificação do cobre o número de argumentos que podem ser é fundamentalmente ilimitado. ${ }^{53}$ Vale dizer: aos que foram aqui mencionados poderiam ser aditados ainda outros, concernentes à eficiência, praticabilidade, justiça, razoabilidade, etc. Isso não significa que a classificação aqui proposta seja despicienda. Bem ao contrário: ela é fundamental como projeto móvel de agrupamento segundo o fundamento de cada argumento, ainda que as nuanças de cada um dele soberbas dificuldades. argumentos não pode ser rígida, pois ela não utilizados na justificação da interpretação, que

não seja totalmente predizivel antes mesmo da interpretação.

Em segundo lugar, a classificação dos argumentos não pode ser inflexível, porque, antes da interpretação, também não se sabe qual dos argumentos será mais seguro ou mesmo qual deles será pertinente à decisão de interpretação. ${ }^{54}$ Em alguns casos, serão os elementos lingüísticos e sistemáticos que irão decidir qual das alternativas interpretativas deverá ser escolhida; em outros, pela vagueza desses elementos, só os argumentos históricos é que poderão resolver a questão interpretativa. E assim sucessivamente. É dizer: a pertinência dos argumentos depende do próprio problema posto à prova.

Em terceiro lugar, a classificação dos argumentos não pode ser rija, porque, apesar de ela ser elaborada em razão da plausibilidade da recondução de cada argumento ao ordenamento jurídico, essa recondução não está predefinida; ela deve ser construída. Isso suscita, evidentemente, dúvidas a respeito da qualificação desse ou daquele argumento como sendo lingüístico, sistemático, histórico, genético ou meramente prático.

Em quarto lugar, a classificação dos argumentos não pode ser austera, na medida em que os argumentos não são estanques entre si; eles, inversamente, interagem reci procamente. Algumas vezes, serão os próprios argumentos sistemáticos que irão demonstrar a insuficiência dos argumentos lingüísticos; noutras situações, somente os argumentos históricos é que irão revelar a deficiência dos argumentos sistemáticos, pela alteração das circunstâncias temporais ou espaciais. Nessas hi póteses, não será sequer racionalmente demonstrável a desunião de argumentos que se encontram amalgamados.

3 KAUFMANN, Arthur. Rechtsphilosophie. 2. ed. München: Beck, 1997. p. 47.

54 LOOSCHELDERS, Dirk. ROTH, Wolfgang. Juristische Methodik im Prozess der Rechtsanwendung. Berlin: Duncker und Humblot, 1996. p. 194.

Revista da Faculdade de Direito da UFRGS, v. 19, Março/2001
B. As condições das quais depende a mas nem sempre é assim. É que o contexto é força justificativa dos argumentos

A pertinência e a relevância de cada argumento para a interpretação depende da implementação de determinadas condiçōes. Como já exposto, e inclusive demonstrado pelo exemplo da imunidade aqui tratado, embora sejam implementadas as condições de aplicação de um argumento, ele pode não ser suficiente para justificar uma interpretação.

Os argumentos lingüísticos podem se satisfatoriamente empregados na interpretação se a norma for inteligivel no contexto da linguagem ordinária. Ocorre que a linguagem ordiná ria pode, como visto, apresentar várias características que se contrapõem àquela inteligibilidade mais imediata: vagueza, ambigüidade, variedade de uso, falta de especificidade aplicativa, falta de atualidade. ${ }^{55}$ Não é por outro motivo que as normas semanticamente mais abertas, e quaisquer outras em menor medida, não podem ter seu significado determinado com apelo apenas à linguagem, como é o caso dos princípios jurídicos e das cláusulas gerais. O recurso aos outros argumentos é imprescindível.

Os argumentos sistemáticos podem se satisfatoriamente empregados na interpretação se o contexto e os precedentes apontarem para uma só direção. Isso, como visto, pode ocorrer, variado; e os precedentes, nem sempre uniformes. O decisivo, no entanto, é que as relações entre os elementos do sistema não estão predeterminadas; devem ser construídas num verdadeiro "esforço de contextualização". ${ }^{56}$ Isso permite uma variedade de composições que irão constituir o que só ao final poderá ser chamado de "contexto". Além disso, somente no processo de interpretação é que se poderá perceber a relevância dos elementos que compõem o contexto normativo: há elementos e elementos no ordenamento jurídico.

Os argumentos transcendentes ao ordenamento jurídico passam a ser relevantes na interpretação no momento em que a linguagem e o sistema já não proporcionam uma justificação para a interpretação. Se o intérprete consegue construir um significado de acordo com argumentos lingüísticos e sistemáticos, não há razão suficiente para o recurso a outros argumentos. ${ }^{57}$ Não é noutro sentido que a doutrina constrói as etapas na argumentação jurídica: só se recorre à próxima etapa se a anterior for insuficiente para a justificação da interpretação. ${ }^{58}$

De acordo com a tese aqui defendida, os argumentos lingüísticos estão unidos aos sistemáticos. Afinal, como lembra FREITAS, a interpretação jurídica ou é sistemática ou não é interpretação. ${ }^{59} \mathrm{Em}$ razão disso, poder-se-ia for-

${ }_{55}$ MacCORMICK, Neil. SUMMERS, Robert. Interpretation and Justification. In: Interpreting statutes: a comparative study. Org. Idem. Aldershot, Brokfield, Hong Kong, Singapore, Sydney: Dartmouth, 1992. p.
516 .

${ }_{56}$ CARVALHO, Paulo de Barros. Proposta de modelo interpretativo para o direito tributário. In: Revista de Direito Tributário (70):42, São Paulo: Malheiros.

"7 LARENZ, Karl. CANARIS, Claus-Wilhelm. Methodenlehre der Rechtswissenschaft. 3. ed. Berlin: Springer, 1995. p. 163 e ss. BYDLINSKI, Franz.Juristische Methodenlehre und Rechtsbegriff. 2. ed. Wien-New York: Springer, 1991. p. 553.

\&ARENZ, Karl. CANARIS, Claus-Wilhelm. Methodenlehre der Rechtswissenschaft. 3. ed. Berlin: Springer, 1995. p. 163 e ss. LOOSCHELDERS, Dirk. ROTH, Wolfgang. Juristische Methodik im Prozess der Rechtsanwendung. Berlin: Duncker und Humblot, 1996. p. 175.

50 FREITAS, Juarez. A interpretação sistemática do Direito. São Paulo: Malheiros, 1995. p. 49.

Revista da Faculdade de Direito da UFRGS, v. 19, Março/200 
mular o seguinte quadro explicativo das etapas da argumentação jurídica, da seguinte forma:

\begin{tabular}{|l|l|l|l|}
\hline Lingüísticos & & & \\
\hline Sistemáticos & & & \\
\hline & Históricos & & \\
\hline & & Genéticos & \\
\hline & & & Práticos \\
\hline
\end{tabular}

Segundo a proposta aqui defendida, essas etapas argumentativas não são estanques. Trata-se, na verdade, de um modelo que, em vez de negar a ultrapassagem aos argumentos transcendentes ao ordenamento juridico para a configuração dos argumentos lingüísticos e sistemáticos, admite-a, mas a condiciona à demonstração de que existem razões suficientes para a superação da força justificativa desses argumentos.

A ausência de limites precisos entre as etapas mencionadas fica evidente naqueles casos em que só se pode mesmo verificar a insuficiência justificativa da etapa anterior se se recorre a posterior. Vale dizer: circunscrever a interpretação aos elementos lingüísticos, a pretexto de que eles fornecem uma interpretação satisfatória, é desconhecer que outros elementos podem inverter a primeira impressão. Os ar-

C. Interação dos argumentos

1. Quadro esquemático

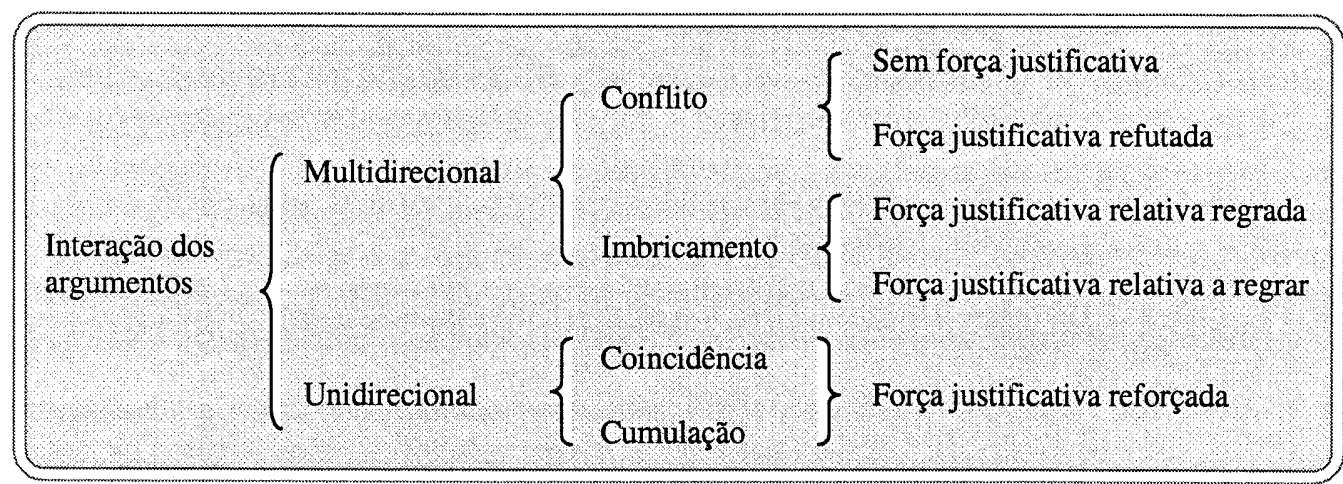

क AARNIO, Aulis. Denkweisen der Rechtswissenschaft. Wien, New York: Springer, 1979. p. 140.

Revista da Faculdade de Direito da UFRGS, v. 19, Março/2001
Os argumentos podem entrar em conflito. Em primeiro lugar, quando um argumento aparenta ter suas condições de justificação preenchidas, mas a análise sob o ângulo de outros logo revela que aquelas condições para que o argumento pudesse justificar uma dada intepretação não estão presentes. É o caso dos argumentos lingüísticos que têm evidenciada sua ambigüidade e vagueza. ${ }^{61}$

No caso da imunidade dos livros, a coninterprete que possui a adequada dimensão $d$ estrutura do sistema jurídico, e analisa qualquer caso "a partir" do sistema, poderão ser superados por argumentos sistemáticos..$^{60}$ Os argumen tos históricos poderão alertar para uma alteracão na situação de fato que motivou a edição da norma, alterando, nesse sentido, o significado imediatamente obtido por meio da análise de outros argumentos. $\mathrm{E}$ assim por diante.

Justamente porque os argumentos não são autônomos entre si, mas interagem de diversas formas, é preciso aprimorar um modelo de etapas sucessivas e subsidiárias na interpretação, que pressupõe autonomia dos argumentos entre si, em favor de um modelo de interação e de valoração dos argumentos. ento, apesar de ter suas condições de justificação implementadas, tem sua força justificativa refutada pela consideração de outros argumen tos. Esse é o caso da relação entre os argumentos lingüísticos e os sistemáticos: o sentido imediato da linguagem ordinária é desde logo refu-

tado pela consideração do contexto normativo. significado unívoco a respeito da consideração de que só há livros de papel; um exame mais aprofundado logo evidencia a existência de obras que, apesar de serem feitas de plástico ou não deixam de serem consideradas livros; também indica a existência de encadernações que, apesar de feitas de papel, não são havidas como livros para efeitos de imunidade, como é o caso do livro de registro ou dos livros em branco. $O$ importante é que essa ambigüidade é apenas revelada por uma interpretação teleológico-sistemática.

No caso da imunidade dos livros, a consideração dos argumentos relativos à linguagem ordinária poderia levar ao entendimento de que a imunidade só protege o livro em papel; a análise dos princípios constitucionais, em especial da liberdade de comunicação, e a interpretação teleológica preconizada pelo Supremo Tribunal Federal logo retrucam a força justificativa potencialmente imediata dos argumentos meramente lingüisticos.

Os argumentos podem entrecruzar-se. Esse entrecruzamento dos argumentos impõe o estabelecimento de regras de prevalência. Pode ocorrer que já existam regras de prevalência previamente instituídas pelo sistema, quer pela jurisprudência, quer pelo próprio direito positivo, na hipótese de contar uma disposição de princípios constitucionalmente estabelecida. ${ }^{62}$ Nessa hi pótese, a convergência de argumentos numa direção também funcionará como critério para a criação de regras de prevalência: o peso relativo a favor de uma interpretação em relação a outra é condicionada pela força, ou força cumulativa, dos argumentos que a suportam, como se demonstra a seguir. ${ }^{63}$

Pode ocorrer, no entanto, que não haja qualquer regra de prevalência previamente estabelecida. Nesse caso, diante das circunstâncias do caso concreto, é preciso atribuir uma dimensão maior de peso a um deles.

2. Interação unidirecional

Os argumentos dificilmente são empre-

of MacCORMICK, Neil. SUMMERS, Robert Interpretation and Justification. In: Interpreting statutes: a comparative study. Org. Idem. Aldershot Brokfield, Hong Kong, Singapore, Sydney: Dartmouth, 1992. p. 528.

a2 ÁVILA, Humberto Bergmann. A distinção entre princípios e regras e a redefinição do dever de proporcionalidade. Revista de Direito Administrativo, (215):168, 1999.

63 MacCORMICK, Neil. SUMMERS, Robert Interpretation and Justification. In: Interpreting statutes: a comparative study. Org. Idem. Aldershot, Brokfield, Hong Kong, Singapore, Sydney:Dartmouth, 1992. p. 528. 
gados separadamente. Mesmo que possam ser agrupados, os argumentos pertencentes a um grupo podem apontar para várias alternativa de interpretação. Pode ocorrer, no entanto, que a interpretação logo revele que os argumentos pertencentes ao mesmo agrupamento, ou mesmo mutuamente independentes, seguem a me ma direção. Quando isso ocorrer, a interpretação ganha uma força justificativa acumulada. ${ }^{64}$

Essa unidirecionalidade normalmente surge em função de determinados argumentos serem suportados por princípios. Nessa hi pótese, entra em cena a idéia de coerência do sistema jurídico: um sistema jurídico é tanto mais coerente quanto maior for a cadeia de fundamentação que ele contiver, e quanto mais proposições forem suportadas pelo menor número de princípios. ${ }^{65} \mathrm{~A}$ idéia de coerência, justamen te por que se relaciona com a concepção de racionalidade e generalidade inerente ao Estado de Direito, reforça a justificação de uma determinada interpretação. Quando maior a cadeia de fundamentação, maior a estrutura de estabilidade dos valores, e maior a força justificativa dos argumentos.

III - VALORANDOS OS ARGUMENTOS JURÍDICOS

A. O papel dos princípios constitucionais

Se todos os argumentos jurídicos são

potencialmente multidirecionais, não é apenas a distinção dos argumentos que irá decidir sobre uma alternativa de interpretação. Isso só será feito se for atribuída a cada argumento uma dimensão de peso. Mas como atribuir uma dimensão de peso?

Nesse sentido, há dois caminhos complementares a serem seguidos para saber o peso de cada argumento na interpretação jurídica. De um lado, é preciso analisar quais são as im plicações metodológicas que decorrem dos elementos essenciais da idéia de Direito - justiça, segurança jurídica, adequação - e das condições formais de conhecimento do próprio sistema jurídico - unidade, consistência e coerência ${ }^{66}$

De outro, faz-se necessário verificar quais são as determinações que resultam das própria normas constitucionais - sobretudo das normasprincípios - no que se refere ao peso dos argumentos utilizados na interpretação. ${ }^{67} \mathrm{~A}$ idéia é simples: os argumentos têm sua força justificativa na medida em que eles são fundados em valores constitucionalmente instituídos. ${ }^{68}$

Nesse sentido, é preciso inicialmente analisar os princípios imanentes ao princípio do rático de Direito (art. 1ㅇ da CF/ 88). O princípio do Estado de Direito estabelece a ligação estrutural entre a atividade do Estado e o Direito; o princípio republicano institui a representatividade com responsabilidade; princípio democrático determina a partici pação

6t MacCORMICK, Neil. SUMMERS, Robert. Interpretation and Justification. In: Interpreting statutes: a comparative study. Org. Idem. Aldershot, Brokfeld, Hong Kong, Singapore, Sydney:Dartmouth, 1992. p. 516.

${ }^{65}$ ALEXY, Robert. Juristische Begründung, System und Kohärenz. In: Rechtsdogmatik und praktische Vernunft. Symposium zum 80. Geburtstag von Franz Wieacker. Org. von Okko Behrends. Göttigen: Vandenhoeck und Ruprecht, 1989. p. 99.

${ }^{\infty}$ BYDLINSKI, Franz.Juristische Methodenlehre und Rechtsbegriff. 2. ed. Wien-New York: Springer, 1991. p. 557. FREITAS, Juarez. A interpretação sistemática do Direito. São Paulo: Malheiros, 1995. p. 105.

or ALEXY, Robert. Juristische Interpretation. In: Recht, Vernunft, Diskurs: Studien zur Rechtsphilosophie. 1. ed. Frankfurt am Main: Suhrkamp, 1995. p. 90.

${ }^{8}$ MacCORMICK, Neil. SUMMERS, Robert. Interpretation and Justification. In: Interpreting statutes: a comparative study. Org. Idem. Aldershot Brokfeld, Hong Kong, Singapore, Sydney:Dartmouth, 1992. p. 532.

Revista da Faculdade de Direito da UFRGS, v. 19, Março/2001 dos cidadãos nas decisões políticas mediante representantes que atuam por meio do procedimento legislativo; o princípio da separação do poderes estabelece que cada um dos Poderes deve exercer suas funções com independência e harmonia. ${ }^{69}$

Diante dessas consideraçōes, logo se ve que os argumentos imanentes ao sistema juríd co têm sua força justificativa fundada no princi pio da separação dos poderes (art. $2^{\circ} \mathrm{da} \mathrm{CF} / 88$ ) e no princípio democrático (art. 1ํㅜㄹ parágrafo único, e art. $5^{\circ}$, inciso $\mathrm{I}, \mathrm{da} \mathrm{CF} / 88$ ). Isso porque o poder parlamentar tem representatividade democrática para tomar decisões; e o respeito essas decisões é um elemento necessário ao prin cípio da separação dos poderes. Os argumento sistemáticos decorrem da idéia de coerência do sistema jurídico, que se deixa reconduzir ao princípios fundamentais do Estado Democrático de Direito (art. $1^{\circ}$ da CF/88), sem os quais, em vez de controle jurídico do Estado, racionalidade do Direito pela clareza previsibilidade e tutela plena dos direitos, há arbitrariedade.

Os argumentos institucionais transcendentes (argumentos genéticos e históricos), por sua vez, não decorrem da força vinculativa do Poder Legislativo. Eles apenas indiretamente podem ser a ele reconduzidos, na medida em que exploram os trabalhos preparatörios ao conteúdo final dos atos legislativos ou visam a reconstruir um momento histórico anterior. Os argu mentos não-institucionais ou meramente práticos nem mesmo indiretamente fazem referência à força vinculativa do Poder Legislativo; eles não se deixam reconduzir, por conseqüência, aos principios imanentes ao Estado Democrático de Direito.

ÁVILA, Humberto Bergmann. Medida Privisória na Constituição de 1988. Porto Alegre: Sérgio Fabris, 1997. p. 48 e 51.

- ALCHOURRÓN, Carlos. Condicionalidad y la representation de las normas juridicas. In: Analisis logico y derecho. Alchourrón y Bulygin. Madrid: Centro de Estudios Constitucionales, 1991. p. 270

${ }^{7}$ ALEXY, Robert. Juristische Interpretation. In: Recht, Vernunft, Diskurs: Studien zur Rechtsphilosophie. 1. ed. Frankfurt am Main: Suhrkamp, 1995. p. 90.

Revista da Faculdade de Direito da UFRGS, v. 19, Março/2001

Diante da relação existente entre os argumentos empregados na interpretação e os princípios constitucionais fundamentais, podese formular algumas regras prima facie de interpretação. Prima facie no sentido de que podem er vencidas por razões contrárias. ${ }^{70}$ Nessa hipótese, porém, as maiores razões deverão ser seguidas de uma fundamentação justificativa.

Como conseqüência do princípio da separação dos poderes e do princípio democrático, é adequado afirmar que os argumentos institucionais devem prevalecer sobre os argumentos não-institucionais. Os argumentos 位 cia o próprio ordenamento jurídico. É precisaargumentação intersubjetivamente controlável. Os argumentos não-institucionais, ao invés de permitirem um debate objetivamente concebível, apóiam-se exclusivamente em opiniōes subas e individuais, contrapondo-se, portanto s exigências de racionalidade e de determinabilidade da argumentação, ínsitas ao princípio do Estado Democrático de Direito.

Em decorrência do princípio da separação dos poderes e do princípio democrático, e também por razões de segurança jurídica, podeafrmar que os argumentos imanentes ao sisa jurídico (argumentos lingüisticos e sistemáicos) devem ter prevalência sobre os argumenem que aquilo que fo mente estabelecido pelo Poder Legislativo deve prevalecer sobre aquilo que deixou de ser estabelecido. ${ }^{71}$ Além disso, a própria 
racionalidade imanente ao Estado de Direito conduz à idéia de previsibilidade do Direito. Previsibilidade essa que só é concebível se as normas puderem ser compreendidas: não é sequer praticável, para que cada norma venha a ser compreendida e seguida, fazer uma pesquisa histórica para ver se o legislador não pretendeu, talvez, dizer algo diferente do que acabou dizendo. As normas devem poder ser compreendidas e seguidas pelos seus destinatários, por isso mesmo que são discutidas, votadas e publicadas. ${ }^{72} \mathrm{E}$ se assim é, aquilo que foi dito (argumentos lingüísticos e sistemáticos) deve prevalecer sobre o que deixou de ser (argumentos genéticos).

Relativamente à imunidade do "livro eletrônico", pode-se afirmar que os argumentos lingüísticos e sistemáticos dever ter prevalência sobre os argumentos genéticos (a proposta de inclusão do "livro eletrônico" teria sido rejeitada pelo legislador constituinte). Os argumentos institucionais devem prevalecer sobre os argumentos não-institucionais (não tributar o "livro eletrônico" traria perda significativa de receita para o Estado no futuro).

O problema, contudo, é que os argumentos lingüísticos e sistemáticos não fluem sô numa direção: há tanto argumentos a favor da imunidade do "livro eletrônico" (o "livro eletrônico" é usado como uma espécie de "livro"; a inserção do "livro eletrônico" na classe dos "livros" evita a contradição com princípios constitucionais fundamentais; o "livro eletrônico" consistiria num simples meio, equivalente ao livro, para garantir a liberdade de expressão e de in formação, o Supremo Tribunal Federal inter-

I2 BYDLINSKI, Franz.Juristische Methodenlehre und Rechtsbegriff. 2. ed. Wien-New York: Springer, 1991. p. 563.

${ }^{73}$ PECZENIK, Aleksander. Grundlage der juristischen Argumentation. Wien; New York: Springer, 1983.p. 180 ss.

${ }^{74}$ RAZ, Joseph. The Relevance of Coherence. In: Ethics in the public domain: essays in the morality of law and politics. Oxford: Clarendon, 1996. p. 288.

Revista da Faculdade de Direito da UFRGS, v. 19, Março/2001 samente os contrarie. ${ }^{75}$ Quanto mais importante for o princípio no ordenamento jurídico, pelo papel fundante que ele exerce sobre os argumentos, mais será relevante o argumento a ele reconduzivel. Afinal, demonstrar que uma in terpretação se situa no âmbito de um fim cuja realização é determinada por um princípio, é também revelar que a regra é valiosa. ${ }^{76}$

Mas com qual ou quais princípios deve a alternativa de interpretação mais intensamente corresponder? Num segundo passo, é preciso analisar a existência de hierarquia entre os princípios constitucionalmente previstos. A hierarquia é, também ela, uma forma de valoração. Nesse passo, entra em cena a idéia de hierarquia axiológica: a Constituição de 1988 põe a lume a maior importância dos seus princípios fundamentais no confronto com outros princípios, como bem expõe SOUTO MAIOR BORGES.7

Diante do exposto, pode-se formular as seguintes regras prima facie de interpretação:

(1) os argumentos institucionais devem prevalecer sobre os argumentos não-institucionais;

(2) os argumentos imanentes ao sistema jurídico (argumentos lingüísticos e sistemáticos) devem prevalecer sobre os argumentos a ele transcendentes (argumentos genéticos e históricos);

(3) na justificação com base em argumentos imanentes ao ordenamento jurídico dever

${ }^{75}$ BYDLINSKI, Franz. Fundamentale Rechtsgrundsätze. Wien; New York: Springer, 1988. p. 127. Idem, System und Prinzi pien des Privatrechts. Wien, New York: Springer, 1996. p. 41 e 43. DWORKIN, Ronald Law's Empire. Cambridge: Harvard, 1986. p. 219, 225. VOGEL, Klaus. Worldwide vs. source of taxation of income - $A$ review and re-evaluation of arguments. International Tax Review (Org.) Fred C. de Hosson, Offprint from Intertax 811/1988, p. 393. GUASTINI, Riccardo. Le fonti del diritto e l'interpretazione.
Milano: Giuffre, 1993. p. 42.

${ }_{76}$ MacCORMICK, Neil. Legal Reasoning and legal theory. Oxford: Clarendon, 1995. p. 152.

" BORGES, José Souto Maior. Pró-dogmática: por uma hierarquização dos princípios constitucionais. Revista de Direito Público, (1): 145, São Paulo: Malheiros, 1993

Revista da Faculdade de Direito da UFRGS, v. 19, Março/2001

ser escolhido o significado que seja mais coerente com os princípios constitucionais axiologicamente sobrejacentes à norma interpretada.

Aplicando essas considerações ao caso em pauta, pode-se afirmar que há mais razões a que contra ela: os argumentos sistemáticos contextuais e jurisprudenciais suportam mais vro eletrônico" na imunidade dos "livros"; os princípios constitucionais estabelecem como devida a realização da liberdade de comunicave à concretização desse fim; o Tribunal Pleno do Supremo Tribunal Federal tem ampliado o entido imediato do dispositivo constitucional que prevê a imunidade dos "livros" sempre que cuja realização ele visa a servir.

Diante do exposto, chega-se a duas conlusões. Em primeiro lugar, ao entendimento multidirecionais. A rigor, nenhum deles é, por definição, resolutivo, no sentido de indicar uma única alternativa de interpretação. Isso permite afirmar que a interpretação jurídica não é funcãão interna (indicação da estrutura dedutiva de raciocínio), nem com uma justificação externa (indicação dos argumentos utilizados). A jusna (indicação dos argumentos utilizados). A jus-
tificação interna apenas permite demonstrar de 
que maneira as conclusões decorrem logicamente das premissas. Ela não explica, porém, de que modo essas premissas são construídas. A justificação externa, a seu turno, apenas esclarece quais são os argumentos utilizados na construção das premissas do raciocínio jurídico. No entanto, como os argumentos fluem em várias direções, a justificação externa não pode explicar nem como os argumentos devem ser construídos nem quais deles devem prevalecer. Isso não quer dizer que as justificações, interna e externa, sejam desnecessárias. Bem ao contrário: sem uma estrutura racional de pensamento e sem a especificação dos argumento utilizados sequer é iniciado o processo de fundamentação racional das decisões de interpretação.

Em segundo lugar, chega-se à conclusão de que os argumentos são multidimensionais. Nesse sentido, é inadequado, por insuficiente, pretender justificar uma interpretação fazendo apelo meramente à linguagem, ao sistema, história ou à vontade do legislador. Cada um desses argumentos se divide em subespécies que, a seu turno, podem ser divididas também em outras.

Pode-se, por exemplo, pretender justificar uma interpretação fazendo menção ao sig nificado das expressões. Mas será preciso sabe qual significado: o comum ou o técnico? Comum ou técnico de qual expressão, de "livros" ou de "papel"? Pode-se tentar fundamentar uma alternativa de interpretação mencionando o contexto do sistema jurídico. Ainda nesse caso caberá a pergunta: qual contexto? O relativo aos princípios da liberdade de expressão e do livre acesso à informação ou o relativo às regras de competência? Também é possível justificar a interpretação com base na finalidade da norma. Nessa hi pótese, caberá indagar: qual final

dade? Ainda: utilizando a finalidade com que propósito, para reduzir o sentido imediato do dispositivo, ou para ampliá-lo? Mais: reduzir ou ampliar o significado de qual dispositivo, principio ou regra de competência, ou de qual fragmento de dispositivo, "livros" ou "papel"? É também perfeitamente cabível pretender justificar uma interpretação mediante o recurso às decisões do Supremo Tribunal Federal. Nessa hipótese, porém, caberá a pergunta: quais decisões, as que interpretam restritivamente ou extensivamente as imunidades? Por último - ma não por fim - pode-se lançar mão da vontade do legislador para fundamentar uma decisão de interpretação. Ainda assim, restará a dúvida: em qual sentido? Vontade do legislador ligada ao significado de determinada expressão ou relacionada a determinada finalidade que ele pretendia atingir?

Enfim, a mera menção a argumentos é artificio ineficaz para justificar minimamente uma interpretação. Sob as vestes de uma "fundamentação", pode a simplificação dos argumentos esconder uma mera preferência. É dizer: escolher uma interpretação com base no capricho (pura preferência), em vez de o fazer com algum fundamento racional (preferência fundamentada). ${ }^{78}$ Por isso a necessidade de uma sucessiva especificação dos argumentos, sem a qual não há fundamentação intersubjetivamente controlável. E sem uma fundamentação intersubjetivamente controlável não se concretiza o princípio do Estado de Direito, pela inexistência de dois dos seus elementos essenciais: racionalidade do Direito e tutela plena dos direitos.

Mas se nem a justificação interna nem a justificação externa permitem fundamentar completamente a interpretação, o quê torna possível fazê-lo? É a valoração dos próprios argu-

78 WRIGHT, Georg Henrik von. Normen, Werte und Handlungen. Frankfurt am Main: Suhrkamp, 1994. p. 126

Revista da Faculdade de Direito da UFRGS, v. 19, Março/2001 mentos jurídicos que permite saber qual a interpretação mais adequada em face de determinado ordenamento jurídico. Essa valoração deve ser pautada nos próprios princípios constitucionais que fundamentam cada um dos argumentos utilizados na interpretação jurídica. Nessa hi pótese, mais do que metodologia do Direito, o que se tem é metodologia "no" Direito: a pretensão de explicar de modo coerente o ordenamento jurídico implica absorver, na argumentação, aqueles fins cuja realização é elevada a dever pelo próprio ordenamento jurídico. Descrever o ordenamento jurídico sem atentar para as implicações metodológicas decorrentes dos seus próprios princípios fundamentais não é explicá-lo; é menosprezá-lo.

Nesse sentido, é preciso dar prevalềncia aos argumentos que se deixam reconduzir aos princípios inerentes ao Estado Democrático de Direito, como o são os argumentos lingüísticos e sistemáticos. Sendo assim, a privilegiar os princípios fundamentais da Constituição de 1988 deverá ser adotada uma interpretação que conduza à imunidade dos "livros eletrônicos".

A proposta reclassificatória dos argumentos e as regras de prevalência se aplicam, evidentemente, à interpretação de qualquer norma jurídica. É sempre necessário, porque transparente e racionalmente demonstrável, explicar quais os argumentos são utilizados. Trata-se de uma tarefa por fazer.

Exemplo paradigmático da função esclarecedora da especificação dos argumento é o caso das medidas provisórias. É verdade

que há argumentos a favor e contra a reedição e a convalidação de medidas provisórias, como há argumentos também a favor e contra a existência de limites materiais para sua edição. Não é menos verdade, no entanto, que os argumentos lingüísticos (segundo o dispositivo constitucional, a medida provisória só pode ser editada em casos de relevância e urgência, e perde eficácia caso não seja convertida em lei em trinta dias) e os sistemáticos (a Constituição dá primazia funcional ao Congresso Nacional, prevê uma hierarquia axiológica do princípio democrático, estabelece a legalidade estrita e mecanismos abreviadores do procedimento legislativo) terminaram sendo suplantados, na prática constitucional brasileira, por argumentos meramente práticos (o governo precisa de agilidade e flexibilidade para regular a economia, por exemplo). ${ }^{79}$

Todo o exposto termina por explicar, de um lado, a importância dos estudos de linguagem e de teoria dos sistemas para a interpretação do ordenamento jurídico. ${ }^{80}$ De outro, porém, põe em dúvida a validade dos estudos doutrinários, tão comuns entre nós, que menosprezam os argumentos lingüísticos e sistemáticos em favor do exame de argumentos transcendentes ao ordenamento jurídico (genéticos, históricos ou meramente políticos, sociais, econômicos ou filosóficos), os quais são analisados por meio de um sincretismo metodológico pasmoso e obscurante, sem que o intérprete proceda à demonstração de que todos argumentos que utiliza podem ser, de alguma forma, reconduzidos ao ordenamento jurídico que ele supostamente pretende interpretar.

3obre a interpretação sistemática da competência para editar medidas provisórias: ÁVILA, Humberto Bergmann. Medida Privisória na Constituição de 1988. Porto Alegre: Sérgio Fabris, 1997.

on VILANOVA, Lourival. As estruturas lógicas e o sistema do direito positivo. São Paulo: RT, 1977. BORGES, José Souto Maior. O Direito como fenômeno lingüǘstico, o problema de demarcaçâo da ciência jurídica, sua base empírica e o método hipotético-dedutivo. In: Ciência Feliz. Recife: Fundação de Cultura Cidade do Recife, 1994. p. 138. CARVALHO, Paulo de Barros. Curso de Direito Tributário. 11. ed. São Paulo: Saraiva, 1999. p. 1 ss.

Revista da Faculdade de Direito da UFRGS, v. 19, Março/2001 
A classificação e as regras de prevalência aqui propostas visam a oferecer uma estrutura racional para a argumentação jurídica que seja vinculada ao ordenamento jurídico, e com a qual possa ser diminuída a subjetividade na interpretação em favor de uma intersubjetividade cada vez maior. Um resíduo, maior ou menor, de subjetividade é inerente a qualquer interpretação. Quando se afirma que há uma parte objetiva e um resíduo de subjetividade na interpretação não se está pretendendo dizer que há fases que são somente objetivas e fases que são somente subjetivas. Não. Desde a mani pulação dos argumentos lingüísticos até o extremo da utilização de argumentos meramente práticos há uma insuplantável dialética entre objetividade $e$ subjetividade. $\mathrm{O}$ esforço do intérprete, e a função mesma da argumentação jurídica, é intersubjetivar o subjetivo. No final, restará um quê de subjetivo na argumentação. Mas um subjetivo que se pode ver. Na verdade, a argumentação jurídica não aniquila a subjetividade; mantem-na sob controle crítico.
O que deve ficar claro é que não se pode tolerar, num Estado Democrático de Direito, uma "justificação" que, a pretexto de fundamentar uma interpretação, termine por encobri-la. Ora, fundamentar é justamente proporcionar acesso interpessoal às razões que motivaram determinada decisão de interpretação. Esse esclarecimento é possível de ser feito; e deve ser levado a cabo não só pelo Poder Judiciário, mas também pela doutrina. Fundamentar é, pois, como levar alguém para um passeio informando-lhe o ponto de partida e o de chegada, o veículo de transporte e as razões da viagem. Deixar de informar o passageiro a respeito disso é fazer aquilo que os seqüestradores fizeram com Maruja, personagem do romance de GABRIEL GARCÍA MARQUES: "No se veía ninguna luz A Maruja le cubrieron la cabeza con una chaqueta y la hicieron salir agachada, de modo que lo único que veía eran sus propios pies avanzando, primero a través de un patio, y luego tal vez por una cocina de baldosines". 8

\section{Os Danos à Pessoa no Direito Brasileiro e a Natureza da sua Reparação}

\author{
Gudith Martins-Costa \\ Doutora em Direito Universidade de São Paulo.
}

Professora Adjunta de Direito Civil e de Teoria Geral do Direito Privado na Faculdade de Direito da Universidade Federal do Rio Grande do Sul .

"Para argumentar não basta, com efeito, possuir toda a sua razão; é preciso ver-se coagido a usála. O pensamento é nosso; mas a inspiraçầo vem de outro lugar. Tu falas, logo eu penso". ALAIN FINKIELKRAUT, A INGRATIDÃO

\begin{tabular}{|l|}
\hline \multicolumn{1}{|c|}{ SUMÁRIO } \\
Introdução. \\
I- Os Danos à Pessoa como Espécies de \\
Danos Extrapatrimoniais. \\
A. Classificação dos danos à pessoa; \\
B. A Relação entre os Danos à Pessoa e \\
o Dano Moral; \\
II - A Satisfação dos Danos à Pessoa. \\
A. A liquidação; \\
B. O Caráter da Condenação: rumo à \\
pena privada?
\end{tabular}

\section{INTRODUÇÃO}

If idéia de dano está no centro do instituto da responsabilidade civil, ligando-se muito proximamente ao valor que historicamente é dado à pessoa e às suas relações com os demais bens da vida. Se o mais relevante for a relação entre a pessoa e os bens patrimoniais, economicamente avaliáveis, cresce em importância a responsabilidade patrimonial, na qual a pessoa é vista tão só como sujeito titular de um patrimônio que, tendo sido lesado por outrem, deve ser recomposto. Se, ao contrário, em primeiro plano está a pessoa humana valorada por si só, pelo exclusivo fato de ser pessoa - isto é, a pessoa em sua irredutivel

1 Texto apresentado no Colloquio Internazionale L'Unificazione del Diritto in America Latina: Principi e Regole Comuni in Materia di Responsabilità Extracontrattuale, Roma, junho de 2000 e que integra Grupo de Pesquisa bases para a Unificação do Direito Privado no MERCOSUL coordenado pela autora. Agradeço à acadêmica de Direito Ana Lúcia Aguiar, bolsista do CNPq-PIBIC sob minha orientação, o auxílio na coleta dos subsídios jurisprudenciais e na revisão das notas.

Revista da Faculdade de Direito da UFRGS, v. 19, Março/2001
${ }^{8}$ GADAMER, Hans-Georg. "Vom Wort zum Begriff. Die Aufgabe der Hermeneutik als Philosophie". In: Die Moderne und die Grenze der Vergegenständlichung. Org. Bernd Klüser. München: Bernd Klüser, 1996. p. 30.

Revista da Faculdade de Direito da UFRGS, v. 19, Março/2001 